\title{
Educational Response Toward COVID-19 Pandemic: Perception, Problems and Prospects; A Bangladeshi Context
}

\author{
Mansura Nusrat
}

\section{ABSTRACT}

This study set out to unearth the perception regarding the effectiveness of online education, problems and future prospects of online education according to the teachers and students of Higher education institutions of Bangladesh during the covid-19 pandemic situation. The present study is conducted in two stages. The first stage was examining the existing literature on Education's (Teaching-Learning) response during the Covid-19 pandemic situation; and in phase 2, one structured questionnaire was administered to elicit responses from students from two different universities in Bangladesh and one semi-structured questionnaire were administered to bring forth responses from teachers of different higher education institutions of Bangladesh. random sampling and the snowball technique were used to develop the sample of 118 respondents with a response rate of $\mathbf{4 4 . 0 3}$ percent. Teachers and students both have positive attitude toward online education during pandemic situation mostly because of safety issue. Positive relationship is found between the level of proficiency of teaching technology and the level of comfort in online teachings among teachers of higher education. Moreover, there are multiple issues at hand to resolve and move forward such as: developing digital proficiency of both teachers and students, ensuring better students' engagement, employing effective and authentic evaluation process, remodeling pedagogy and learning instruments, ensuring quality internet facility at affordable price for all the concerned stakeholders. Current study would help the education practitioners to focus on improving the current issues and thus making the policy regarding teaching during and after pandemic situation owing to the fact that, evidences suggest that, world's education practice is moving toward blended learning (a combination of online and offline, on campus learning). Whereas, several studies have been carried out to reveal the prospects and challenges in the field of education during Covid-19 pandemic. The currents study synthesizes the major contributions and highlights the issues regarding the educational response toward Covid-19 Pandemic around the world. Moreover, this study reveals the problems and prospects of online education during and post Covid-19 era in a third world like Bangladesh.

Keywords: Covid-19, Educational Response, E-Learning, TeachingLearning.

Published Online: September 28, 2021

ISSN: 2736-4534

DOI: $10.24018 /$ ejedu.2021.2.5.163

\section{Mansura Nusrat*}

Department of Business Administration, Bangladesh University, Dhaka, Bangladesh.

(e-mail: brupeen ${ }^{\circledR}$ gmail.com)

*Corresponding Author

\section{INTRODUCTION}

The global Covid-19 pandemic has spread worldwide [1], affecting 219 countries and territories to date, with estimates of up to $12,60,68,653$ people infected [2]. The pandemic has caused massive shocks to national economies and global economic orders, in addition to the devastating loss of family members and loved ones and worldwide illhealth. Lockdowns and suspensions of many economic operations have resulted in widespread unemployment, increased poverty, and denial of basic necessities to poor people and communities [3]. The crisis, on the other hand, has resulted in the creation of collaborative networks, neighborhood cohesion, and a rise in volunteerism, resulting in a significant shift in people's actions (from individuality to collectivity), a shining example of collective involvement and humanity that has demonstrated the power of skilled capital [4].

Whereas, lockdown and social distancing measures due to the COVID-19 Pandemic have led to closures of schools, training institutes and higher education facilities in most countries [1]. The answer of UNESCO as an educational organization strongly supports the introduction of a learning network for distance learning efforts, allowing students to learn from wherever they are [5]. Despite the difficulties faced by both educators and students, online learning, distance learning, and continuing education have become a 
panacea for this ongoing global pandemic [1].

Previously, non-formal education included e-learning, distance education, and correspondence courses; however, it seems that if the current conditions continue to prevail, it would eventually overtake the formal education system [6]. Despite the fact that, along with low physical activity, the nature of group learning, group classroom activities are being skipped by both educators and students [7], one study found that respondents had positive experiences in implementing the E-learning classroom as an immediate response to the country's increased quarantine situation [8]. However, research reveals such deficiencies, like the lack of online teaching infrastructure, teachers' minimal online teaching experience at home, equity, and academic excellence in higher education [1].

About a decade ago, research of over 50,000 faculties from 69 separate institutions [9] solidified the idea that online education requires more time and effort, based on personal experience. Despite the multiple research findings that indicate that online education can be performed extremely well, it has also been acknowledged for some time that online education can also be done poorly [10].

Many scholars have shared their work on teaching and learning in various ways in the aftermath of the COVID-19 pandemic. Innovation and implementation of alternative educational systems and evaluation methods are urgently needed. The COVID-19 pandemic has given us the ability to pave the way for digital learning to be applied [1].

\section{A. Purpose and Problem Statement}

Since, Bangladesh is an over populated county consisting of 42.7 million student population. Bangladesh government took a bold initiative to keep the educational institutions closed for over a year now (since $17^{\text {th }}$ March, 2020) to limit the contract of the virus and encouraged all concerned parties to implement online education system. The current study is set out to unearth:

1. The perception regarding the effectiveness of online education according to the teachers and students of Higher education institutions of Bangladesh during the covid-19 pandemic situation.

2. The challenges and prospects faced by the teachers and students of Higher education institutions of Bangladesh during the covid-19 pandemic situation.

3 . The prospect of online/blended learning in Higher education institutions of Bangladesh after the pandemic situation.

\section{LITERATURE REVIEW}

As school closures due to the COVID-19 virus began in Wuhan and other areas of China in February 2020, a number of INEE (Inter-agency Network for Education in Emergencies) participants and other key stakeholders attempted to fund the affected children's schooling. Within weeks, COVID-19 had turned into a global pandemic, with 1.5 billion pupils out of school globally, accounting for $90 \%$ of all learners [11].

As a result of the ongoing crisis, school leadership has turned radically toward distributed, collective, and network activities [12]. During this phase of crisis, students, instructors, learners, and neighborhoods have sought research-based transformative insights, real-life scenarios, and realistic tools for considering inclusive education curriculum frameworks [3]. In addition to this pandemic situation, collective reactions and research showed that not only technology, but also technicalities are needed to operate the education system smoothly [13].

Mishra [6] used a survey (among 260 students and 78 faculty members) to Identify online teaching modes and the methods of use among students and faculties of Mizoram University, India. The analysis revealed that, despite of having their own Learning Management System (LMS), Most of the teachers and students were using WhatsApp/ Telegram and Email for submission of assignments, educational interactions, conducting class tests, and clarifying doubts. $45 \%$ teachers were using Zoom/Cisco WebEx/Google Meet/Skype platform for conducting online classes, whereas $32 \%$ teachers were using Google classroom, but the recipient students were found to be only $15 \%$ and $20 \%$, respectively.

One study [14] shows from regression analysis that information and communication technology (ICT) tools, especially digital teacher proficiency and teacher education opportunities to learn digital proficiency, are crucial while switching to online teaching during COVID-19 school closures.

Moreover, a significant and detailed analysis was conducted [15] using the School Barometer, a fast survey (due to reaction time, dissemination time, and time to answer) that was accompanied in Germany, Austria and Switzerland during the initial weeks of the school lockdown to appraise current school situation caused by COVID-19. Later, the School Barometer was expanded to an international survey, and some countries accompanied the survey in their own languages. 'In Germany, Austria and Switzerland, 7116 persons participated in the German language version: 2222 parents, 2152 students, 1949 school staff, 655 school leaders, 58 school authority and 80 members of the school support system'. This study reveals that, A substantial proportion of students reported a worryingly low level of learning at home during the school lockdown [15]. Similarly, a study of 282 University students of Malaysia [16] reveals that, During the MCO era, students' engagement and learning success suffered as a result of using online learning methods owing to a lack of infrastructure to support the learning and social support from the lecturers and peers.

In addition to the Three Challenges of Online Learning: i) Interactivity, ii) Authenticity, iii) Support [10], according to [17], In low-income areas as well as within medium- and high-income nations, there is an unequal capacity in terms of reaction and planning to cope with the learning losses arising from school closure. Similarly, another study [18] found that, in underdeveloped countries like Pakistan, where the vast majority of students are unable to access the internet due to technological and financial problems, online learning cannot yield the desired results. Students in higher education complained of a lack of face-to-face contact with instructors, as well as long reaction times and a lack of typical classroom socialization. 


\begin{tabular}{|c|c|c|c|c|}
\hline $\begin{array}{l}\text { Sl. } \\
\text { No. }\end{array}$ & Study, Context & Journal & Title & Purpose and Methodology \\
\hline 1. & $\begin{array}{l}{[6]} \\
\text { Bhutan }\end{array}$ & $\begin{array}{l}\text { International } \\
\text { Journal of } \\
\text { Educational } \\
\text { Research Open }\end{array}$ & $\begin{array}{l}\text { Online teaching-learning in } \\
\text { higher education during } \\
\text { lockdown period of COVID-19 } \\
\text { pandemic }\end{array}$ & $\begin{array}{l}\text { Purpose: discusses the necessary essentials of online teaching-learning } \\
\text { in education in the face of the COVID-19 pandemic, and how can } \\
\text { current educational institution resources effectively turn formal } \\
\text { education into online education with the aid of virtual classes and } \\
\text { other pivotal online tools. } \\
\text { Methodology: quantitative and qualitative approach. }\end{array}$ \\
\hline 2. & $\begin{array}{l}{[12]} \\
\mathrm{UK}\end{array}$ & $\begin{array}{l}\text { Journal of } \\
\text { Professional } \\
\text { Capital and } \\
\text { Community }\end{array}$ & $\begin{array}{l}\text { COVID-19-school leadership } \\
\text { in crisis? }\end{array}$ & $\begin{array}{l}\text { Purpose: investigates how school leaders are reacting to COVID-19 } \\
\text { and what new leadership models are emerging. } \\
\text { Methodology: Literature Review. }\end{array}$ \\
\hline
\end{tabular}

3. [5] Sys Rev Pharm

Indonesia

\section{4. [8]}

\section{Philippines}

Journal of Critical
Reviews

Reviews
Education and
5. [10]

\section{Canada}

6. [13]

Bangladesh

7. [1]

Bhutan

8. [14]

Germany

9. [15]

Germany,

Austria and

Switzerland

\section{0. [18] \\ Pakistan}

11. [17]

Spain

12. [19]

Philippine

Canadian Journal Technology

Asian Journal of Social Studies

Higher Education for the Future

European Journal of Teacher Education

Educational Assessment, Evaluation and Accountability

Journal of Pedagogical Sociology and Psychology Sustainability

International Journal of Pedagogical Development and Lifelong Learning

$\begin{array}{lll}\text { 13. }[3] & \underline{\text { Journal for }} \\ \text { USA } & \underline{\text { Multicultural }} \\ & \underline{\text { Education }}\end{array}$

Covid-19 pandemic and home online learning system: does it affect the quality of pharmacy school learning?

The status of the implementation of the elearning classroom in selected higher education institutions in region iv-a amidst the covid-19 crisis

Education's Response to the Covid-19 Pandemic Reveals Online Education's Three Enduring Challenges Impact of COVID-19 on the Institutional Education System and its Associated Students in Bangladesh

A Literature Review on Impact of COVID-19 Pandemic on Teaching and Learning

Adapting to online teaching during COVID-19 school closure: teacher education and teacher competence effects among early career teachers in Germany

COVID-19 and schooling: evaluation, assessment and accountability in times of crises - reacting quickly to explore key issues for policy, practice and research with the school barometer

Online learning amid the COVID-19 pandemic: Students' perspectives

The Right to Education and ICT during COVID-19: An International Perspective

The COVID-19 Pandemic through the Lens of Education in the Philippines: The New Normal

An action research case study: digital equity and educational inclusion during an emergent COVID-19 divide
Purpose: The aim of this research is to determine and collect data on the effect of the Covid-19 pandemic on the learning process.

Methodology: Literature review.

Purpose: This action research examines the status of the E-Learning classroom implementation in selected HEIs.

Methodology: qualitative approach using a survey questionnaire.

Purpose: Addressing the challenges of Online Education.

Methodology: Qualitative approach.

Purpose: focuses on the effect of the current COVID-19 pandemic on Bangladesh's educational system and potential solutions. Methodology: descriptive survey research design.

Purpose: This study aims to provide a detailed study on the effect of the COVID-19 pandemic on online teaching and learning of different papers, as well as a suggestion for the future.

Methodology: Literature Review.

Purpose: The results of a survey of early career teachers conducted in May and June 2020 are presented in this article.

Methodology: Quantitative and Qualitative.

Purpose: reflects on issues of assessment, evaluation and accountability during the times of crisis.

Methodology: Quantitative

Purpose: In the face of the Coronavirus, this study explores the attitudes of Pakistani higher education students toward mandatory multimedia and distance learning university courses (COVID-19)

Methodology: Quantitative and Qualitative

Purpose: 'this article discusses how COVID-19 has exacerbated inequalities and pre-existing problems in education systems around the world'.

Methodology: interpretative approach

Purpose: This article presents, the latest educational norm, prospects for responding to issues, challenges, and developments that are currently emerging and will emerge in the future as a result of the COVID-19 pandemic, Through the lens of education in the Philippines.

Methodology: Qualitative

Purpose: The aim of this paper is to provide responses from recent literature, a brief case study of the school of education faculty's attitudes and practices toward multicultural and educational concerns during the rapid increase in online environments during coronavirus 


\begin{tabular}{|c|c|c|c|}
\hline 14. & India & $\begin{array}{l}\frac{\text { Asian Association }}{\text { of Open }} \\
\underline{\text { Universities }} \\
\underline{\text { Journal }}\end{array}$ & $\begin{array}{l}\text { Perception towards } \\
\text { online/blended learning at the } \\
\text { time of Covid- } 19 \text { pandemic: an } \\
\text { academic analytics in the } \\
\text { Indian context }\end{array}$ \\
\hline 15. & $\begin{array}{l}\text { [20] } \\
\text { Pakistan }\end{array}$ & $\begin{array}{l}\text { Asian Education } \\
\text { and Development } \\
\text { Studies }\end{array}$ & $\begin{array}{l}\text { The role of digital learning } \\
\text { toward } \\
\text { students' satisfaction and } \\
\text { university brand image at } \\
\text { educational institutes of } \\
\text { Pakistan: a post-effect of } \\
\text { COVID-19 }\end{array}$ \\
\hline 16. & $\begin{array}{l}{[16]} \\
\text { Malaysia }\end{array}$ & $\begin{array}{l}\text { Asian Education } \\
\text { and Development } \\
\text { Studies }\end{array}$ & $\begin{array}{l}\text { The impact of COVID-19 on } \\
\text { student motivation, community } \\
\text { of inquiry and learning } \\
\text { performance }\end{array}$ \\
\hline 17. & India & $\begin{array}{l}\text { Asian Education } \\
\text { and Development } \\
\text { Studies }\end{array}$ & $\begin{array}{l}\text { Online education during } \\
\text { COVID-19: perception of } \\
\text { academic } \\
\text { stress and emotional } \\
\text { intelligence coping strategies } \\
\text { among } \\
\text { college students }\end{array}$ \\
\hline
\end{tabular}

(COVID-19) outbreaks and just-in-time methods for tackling digital equity and educational inclusion in $\mathrm{K}-16$ online educational environment.

Methodology: action research case study

Purpose: to inquire about teachers' and students' perspectives on the use of online/blended learning modes in teaching and learning transactions, and to study more about the opportunities and challenges of providing online/blended learning in a country like India, especially during and after Covid-19.

Methodology: The academic analytics approach

Purpose: Examine the effect of information and communication technology (ICT), as well as the quality of e-services and einformation, on university brand picture by focusing on students' elearning, satisfaction, and e-word of mouth.

Methodology: Quantitative

Purpose: to unearth COVID-19's effect on students enrolled in higher education institutions prior to and after the Movement Control Order (MCO).

Methodology: quantitative analysis (paired sample t-tests)

Purpose: to investigate the students' perceptions of academic stress during on going online education and coping methods using emotional intelligence used by them.

Methodology: Quantitative.
However, Lorente, Arrabal, \& Pulido-Montes [17], concluded that to address the sustainability of education, it is critical to articulate equitable educational policies that promote enhancing government response capability, especially in low-income countries.

The study on the impact of the COVID-19 pandemic on teaching and learning across the world [1]. Although numerous studies have been conducted, appropriate pedagogy and platforms for different class levels in higher secondary, lower, and primary education need to be discussed further in the case of developing countries. In addition to that, Internet bandwidth is limited, with fewer access points, and data packages are expensive in comparison to people's income in many developing countries, limiting connectivity and affordability. To improve the situation, policy action is needed [1].

Digital learning, on the other hand, necessitates selfregulation abilities from students due to the school lockdown [15], meanwhile teachers' proficiencies in both pedagogy and technology should be reinforced [19]. Shehzadi et al. study [20] revealed that Students' e-learning is positively influenced by ICT, e-service quality, and einformation quality, which contributes to positive e-word of mouth and student satisfaction. Meanwhile, the findings showed that e-word of mouth and student retention relate to universities getting a good brand profile.

The study of Bordoloi, Das, \& Das [21] concluded that, seemingly during the pandemic, Teachers in higher education are now using features such as Facebook Live lessons, Google Classroom, Skype tutorials, audio-visual classes via WhatsApp, personal blogs, and meeting applications such as Zoom, Google Meet, and others, which have provided learners with significant relief. However, the "four quadrants" of instruction, including e-materials, video content, discussion boards, and quizzes or multiple-choice questions (MCQs), must not be compromised when delivering online education. As a result, teachers' or content developers'/providers' skill-building must be prioritized so that they become familiar with the basic principles of online learning, aside from overcoming the fear of technology.

\section{METHOD}

The present study is conducted in two stages. The first stage was examining the existing literature on Education's (Teaching, Learning) response during the Covid-19 pandemic situation. The search strategy was developed to locate both academic and non-academic literature. A customized year criterion was used in Google Scholar and emerald insight to find research studies published between 2020 and 2021. Several combinations of phrases, i.e. "Educational response", "Teaching", "Learning", “elearning" and "Covid-19" were applied. Lay publications, opinion pieces, and non-refereed journal articles were discarded after scanning the titles and abstracts. The literature searches and downloaded paper reading were conducted from February to March 2021 and the papers were analyzed in March 2021. In total, 30 papers were downloaded. The full text of all the 30 papers was read and only 17 papers (Table I) were selected for the final review based on the following criteria:

1) published from 2020 to 2021 ;

2) published in the English language;

3) focused on teaching learning during Covid-19 pandemic;

4) published in refereed journals.

The second stage was conducting an online survey of 13 Professors teaching disparate courses in 4 different Higher 
Education institutions of Bangladesh and 105 students studying in 2 different Higher education institutions of Bangladesh. After collecting the data, descriptive and inferential analysis were used to analyze and present the data.

\section{A. Questionnaire}

The researcher developed a structured questionnaire for students and a semi-structured questionnaire for teachers of higher education institutions of Bangladesh, after a thorough literature review (e.g., [18], [21], [8], [15]). Moreover, a pilot survey was done after developing the questionnaire. Appropriate revisions and necessary modifications were done depending on the feedbacks found from the pilot survey before emailing the questionnaire to teachers and students.

TABLE II: DEMOGRAPHICS OF RESPONDENTS (TEACHERS)

\begin{tabular}{|c|c|}
\hline Row Labels & Count of Designation \\
\hline Assistant Professor & 1 \\
\hline Lecturer & 5 \\
\hline Lecturer & 5 \\
\hline Professor and Head & 1 \\
\hline Senior Lecturer & 1 \\
\hline Grand Total & 13 \\
\hline Row Labels & Count of Teaching experience \\
\hline $0-3$ & 6 \\
\hline $3-5$ & 4 \\
\hline $5-10$ & 1 \\
\hline More than 10 & 2 \\
\hline Grand Total & 13 \\
\hline
\end{tabular}

\section{B. Sample}

The questionnaire was made using Google form and the link of the questionnaire was sent to 68 firstly, random selection technique and afterward snowball technique was used to select the teachers of 4 different institutions whereas, 13 teachers (see Table II) responded (response rate $19.12 \%$ ) and 200 randomly selected students of two different higher education institutions whereas, 105 students (see Table III) responded (response rate 52.5\%).

TABLE III: DEMOGRAPHICS OF RESPONDENTS (STUDENTS)

\begin{tabular}{cc}
\hline Row Labels & Count of Age \\
\hline $18-20$ & 9 \\
$21-25$ & 68 \\
$26-30$ & 16 \\
More Than 30 & 12 \\
Grand Total & 105 \\
\hline Row Labels & Count of University \\
\hline Bangladesh University & 59 \\
Sonargaon University & 105 \\
\hline Grand Total & 55 \\
\hline Row Labels & 46 \\
\hline Part time/full time job holder & 105 \\
\hline Full time student & Count of Formal Job Holder \\
\hline Grand Total &
\end{tabular}

\section{DISCUSSION}

This study has tried to unearth the perception of teachers and students of higher education institutions of Bangladesh during the current Covid-19 pandemic and problems and prospects online education during and post covid-19 pandemic in Bangladesh. Collected data were synthesized and interpreted in line with the objectives of this study.

\section{A. Summary of Teachers' Response}

The teachers were asked whether the courses they teach can be taught online or not. All of the teachers unanimously responded positively. However, they further opined that, Elearning is applicable by taking live classes through various platform like google meet/Zoom and providing record of classes. They pointed out that, E-learning helps to reach out to students more efficiently and effectively through chat groups, video meetings and also document sharing. The teachers believe that, eLearning facilitates the learners and the instructor interact with each other in real time, from different places that makes education accessible in COVID19 situation.

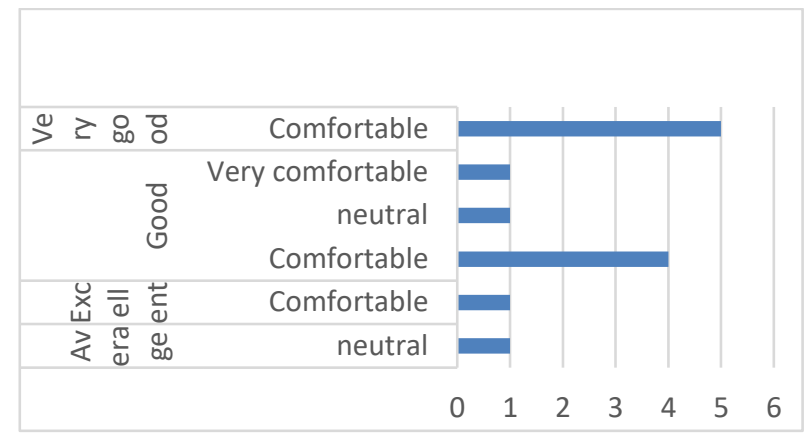

Fig. 1. How comfortable you feel teaching online?

While asked to report their level of proficiency on online teaching technology, mixed results were found. Whereas, six respondents reported to have good command over teaching technology, five respondents reported to have very good command over that. Interestingly, those who reported to have, very good and excellent command over online teaching technology also reported to feel comfortable teaching online (see Fig. 1). On the other hand, those who reported to have average proficiency felt neutral. However, teachers having good command over teaching technology conveyed mixed feelings regarding online comfort in online teaching.

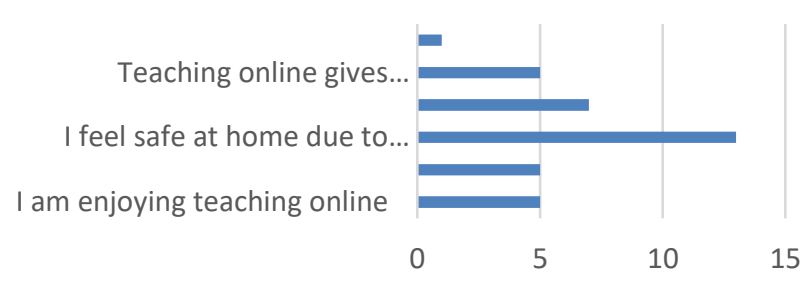

Fig. 2. If you want to continue teaching online, why? (you can select multiple answers).

The teachers were asked whether they want to continue teaching online amidst the current pandemic situation or not and why (see Fig. 2.)? The $100 \%$ teachers opined that they want to continue online teaching amidst pandemic situation for their safety concern. Apart from this, they pointed out other reasons behind their willingness to continue teaching online like: 
- $\quad$ Teaching online saves travel time (53.85\%),

- Teaching online gives schedule flexibility (38.46\%),

- They are enjoying teaching online (38.46\%),

- More students can connect then usual (38.46\%)

- $\quad$ they can enjoy more family time (7.69\%).

Moreover, the teachers were asked about whether they want to go back to traditional on campus classroom teaching after the pandemic situation and why (see Fig. 3.)? The majority of faculties $(92.3 \%)$ mentioned that, they want to go back to on-campus classroom teaching since they miss face to face interaction with students. However, teachers pointed out that, their intention to go back to traditional teaching method is also associated with the facts that are: Teaching online has so many hurdles like network issues (69.23\%), Home environment is not suitable for online teaching $(46.15 \%)$, Teaching online needs more preparation time $(7.69 \%)$. Interestingly, two faculties pointed out that, they do not enjoy teaching online and thus want to go back to on campus teaching. One similar study [5] found where, there are several obstacles experienced by students, teachers and parents in online teaching and learning activities, namely additional internet quota costs, mastery of technology is still lacking, Since teachers must collaborate and interact with parents, other teachers, and school principals, extra work for parents in aiding children in learning has increased, while contact and socialization between pupils, teachers, and parents has decreased, and working hours for teachers have been increased.

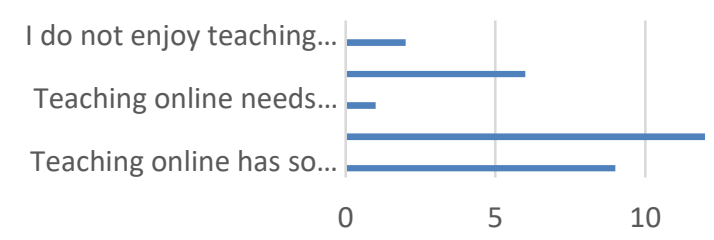

Fig. 3. If you want to go back to traditional classroom teaching, why? (you can select multiple answers).

From the responses of the teachers, it is found that (see Fig. 4.), $100 \%$ of the faculties of higher education institutions of Bangladesh use google classroom, $76.92 \%$ of the faculties use google meet, 53.84\% of the faculties use zoom and $38.46 \%$ use Facebook live as the teachinglearning platform.

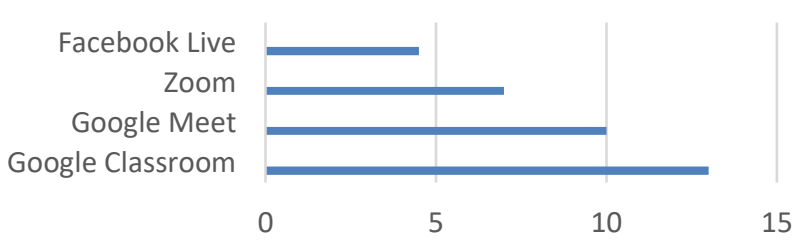

Fig. 4. Learning Platforms used by the teachers.

The teachers were asked to mention the strategies they use to retain the students' attention during the live classes (see Fig. 5.). All the teachers unanimously responded that, they use attendance marks and spot test during classes to ensure attendance and engagement in live classes. Twelve of the faculties frequently ask questions during class mentioning students name and ten of the faculties allow students to participate in the live discussion and encourage them to join in the class via video.

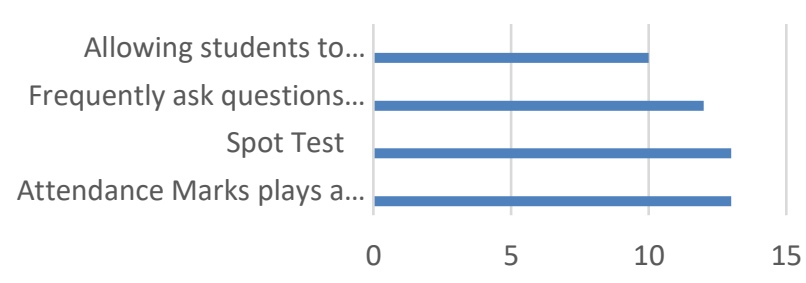

Fig. 5. What strategies you use to ensure students' engagement during live class?

While queried about the students' response regarding online classes, faculties opined that, most of the students have positive responses regarding doing classes online. This finding is congruent with the findings of Mishra [6]where he employed a semi structured interview and the findings suggest that, both teachers and students agreed upon the fact that, online mode of education is useful, and thus it can be managed as a transition mechanism. Similarly, Chua et al. [8] found that, the respondents reported having a positive experience incorporating the E-learning classroom as a timely response to the country's increased quarantine situation. However, few students have mixed feelings regarding online classes, especially during the quantitative classes like mathematics, accounting and finance. Students were also complaining about having network issues, costly data package etc.

Whether the current online evaluation process in Bangladesh is being fair or not were asked to teachers (see Fig. 6.). A mixed result was found. 6 faculties answered positively and 5 faculties answered negatively whereas, 2 faculties were neutral about this.

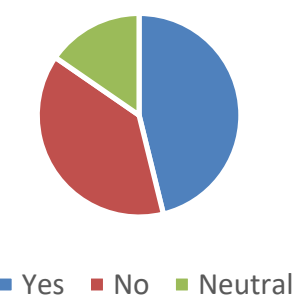

Fig. 6. Do you think the current online evaluation process is fair?

\section{B. Summary of Students' Responses}

From the responses of the students (see Table IV), it is found that, majority of the students (71) encounter problem with internet access mostly owing to the poor connection (53) and costly internet data package (23). However, Majority (74) of the students use smartphone for online education during this crisis period whereas a big portion (67) of them always have access to the digital device. 
TABLE IV: SUMMARY OF STUDENTS’ RESPONSES

\begin{tabular}{|c|c|c|}
\hline \multicolumn{2}{|r|}{ Question } & Response (Total-105) \\
\hline 1. & Do you have any problem with internet access? & $\begin{array}{l}\text { Yes-67.6\% } \\
\text { No- } 32.4 \%\end{array}$ \\
\hline 2. & The main reason for limited Internet access & $\begin{array}{l}\text { Costly-21.9\%, Poor Connection-50.5\%, Signal unavailability- } \\
\text { 7.6\%, Can't Operate-0\%, Other-20\% }\end{array}$ \\
\hline 3. & How often you have access to Smart Phone/ Computer/ Laptop & $\begin{array}{l}\text { Always-63.8\%, Sometimes-30.5\%, Rarely-2.9\%, Never (I } \\
\text { have to use other people's device)-2.9\% }\end{array}$ \\
\hline 4. & $\begin{array}{l}\text { Most effective digital device during the crisis period for online } \\
\text { education }\end{array}$ & $\begin{array}{l}\text { Personal Computer-7.6\%, Laptop-21.9\%, Smartphone-70.5\%, } \\
\text { Other-0\% }\end{array}$ \\
\hline 5. & Most effective content delivery method & $\begin{array}{l}\text { Live online Class-61.9\%, Recorded Video-31.4\%, Digital } \\
\text { books-3.8\%, Other-2.9\% }\end{array}$ \\
\hline 6. & $\begin{array}{l}\text { What education mode would you prefer most post Covid-19 } \\
\text { situation? }\end{array}$ & $\begin{array}{l}\text { Online- } 72.4 \%, \text { Offline-13.3\%, Blended (Combination of } \\
\text { online and offline)-14.3\% }\end{array}$ \\
\hline \multicolumn{2}{|r|}{ The extent to which you agree with the following statements? } & \\
\hline 7. & University courses can be completed effective through internet & $\begin{array}{c}\text { Strongly Agree-30.5\%, Agree-43.8\%, } \\
\text { Disagree-10.5\%, Strongly Disagree-2.9\% }\end{array}$ \\
\hline 8. & $\begin{array}{l}\text { Face to Face contact with the instructor is necessary for effective } \\
\text { learning }\end{array}$ & $\begin{array}{l}\text { Strongly Agree- } 23.8 \% \text {, Agree- } 41 \% \text {, Neutral-21.9\%, Disagree- } \\
10.5 \% \text {, Strongly Disagree- } 2.9 \%\end{array}$ \\
\hline 9. & It is easy to complete group projects/assignments digitally & $\begin{array}{l}\text { Strongly disagree-7.6\%, Disagree-16.2\%, Neutral-15.2\%, } \\
\text { Agree- } 47.6 \% \text {, Strongly agree-13.3\% }\end{array}$ \\
\hline 10. & $\begin{array}{l}\text { The evaluation (examination and marking) process is being fair } \\
\text { online }\end{array}$ & $\begin{array}{c}\text { Strongly Agree-25.7\%, Agree-45.7\%, } \\
\text { Disagree- } 7.6 \%, \text { Strongly Disagree- } 2.9 \%\end{array}$ \\
\hline 11. & Learning at home is challenging & $\begin{array}{ccc}\text { Strongly disagree-9.5\%, } & \text { Disagree-24.8\%, Neutral-20\%, } \\
\text { Agree-36.2\%, Strongly agree-9.5\% } & \\
\end{array}$ \\
\hline 12. & I learn more now than in regular schooling & $\begin{array}{c}\text { Strongly disagree-6.7\%, Disagree-28.6\%, Neutral-28.6\%, } \\
\text { Agree-27.6\%, Strongly agree- } 8.6 \%\end{array}$ \\
\hline 13. & $\begin{array}{l}\text { I waste my time on daily basis surfing internet rather than learning } \\
\text { my school related content }\end{array}$ & $\begin{array}{c}\text { Strongly disagree- } 4.8 \%, \text { Disagree- } 38.1 \% \text {, Neutral-23.8\%, } \\
\text { Agree- } 25.7 \% \text {, Strongly agree- } 7.6 \%\end{array}$ \\
\hline 14. & I have difficulty retaining concentration during live online class. & $\begin{array}{c}\text { Strongly disagree-3.8\%, Disagree-28.6\%, Neutral-19\%, } \\
\text { Agree- } 44.8 \% \text {, Strongly agree-3.8\% }\end{array}$ \\
\hline
\end{tabular}

While asked about most effective content delivery method according to them 65 students supported live online class whereas 34 students supported recorded lecture video. Interestingly, a large portion of the respondents (76) suggested continuing online education even after the current pandemic situation is over.

Students were asked the extent to which they agree with some statements. Some interesting findings were found from these responses. Probably the single most striking and contradictory uncovering is that, though the majority $(62.9 \%)$ of the students believe that, Face to Face contact with the instructor is necessary for effective learning, yet they $(74.3 \%)$ opined that, University courses can be completed effective through internet. However, some 60.9\% students believe that, it is easy to complete group projects/assignments digitally. While asked about the students' opinion regarding the current online evaluation process, majority (67) of the students suggested it is being fair.

Mixed results were found when asked about whether learning at home is challenging or not. While, $45.7 \%$ students opined learning at home is challenging, other $34.3 \%$ students suggested otherwise. Similarly, whereas $35.3 \%$ students claimed that they learned more in traditional schooling than online schooling, other $36.2 \%$ stated that, they learn more now than in regular schooling.

When the students were asked whether they waste their time on daily basis surfing internet rather than learning their school related content, $42.9 \%$ students agreed to the statement and 33.3\% disagreed with it. Students were also asked whether they have difficulty retaining concentration during live online class where, $48.6 \%$ students suggested they face difficulties retaining concentration.

\section{CONCLUSION}

During the COVID-19 lockdown, education modernization, privatization, and globalization suffered a major setback due to restricted mobility and tightly regulated academic exchange programs among countries [6]. With their broken technological systems, academic incompetence, and shortage of funding, third-world countries are experiencing policy inertia in dealing with the unexpected changing scenario of educational preparation, administration, and organization during this pandemic; Low and middle-income countries, in particular, would suffer the most setbacks, since they were still short of funds [22]. There are numerous problems ahead, as the worldwide downturn is far from over; education has never been more urgent, crucial, or in desperate need of protection from the current storm. School leaders play a critical role in navigating a stable, principled, and collective passage through, ensuring that all students have better days ahead of them [12]. To contend with the complexities of online education, designing multimodal methods to meet course material goals for improved learning outcomes could be a better idea. Governments must remain unfazed in their efforts to ensure the provision of secure networking resources, high-quality digital academic experience, and more, and promote technology-enabled learning for students to close the disparities that existed in the educational system before and after the COVID-19 crisis, which is also unavoidably necessary for continuous learning [6]

\section{A. Suggestions:}

While, several studies found evidences supporting the fact that, online mode of study is the best solution during current 
unprecedented situation, there are multiple issues at hand to resolve and move forward such as: developing digital proficiency of both teachers and students, ensuring better students' engagement, employing effective and authentic evaluation process, remodeling pedagogy and learning instruments, ensuring quality internet facility at affordable price for all the concerned stakeholders.

From the responses collected from the teachers and students of higher education institutions of Bangladesh, the researcher came up with several suggestions as follows:

1. Government should intervene to reduce the cost of data package and to improve the quality of cellular network especially in the remote areas to ensure effective and uninterrupted teaching-learning.

2. Teachers of qualitative courses in association with school leaders need to rethink and redesign the current course outline and bring forth a better study plan which would be conducive to online teaching-learning.

3. Online evaluation process should be redesigned in line with learning outcome and which would prevent students from practicing any unethical means.

4. Students should take self-regulatory actions to check wasting time surfing internet rather than learning and to retain concentration during live classes.

5. Students need to be self-motivated to expedite selflearning at home and manage stress during this turbulent situation.

6. Rather than solely anchoring on learning, all concerned parties should be more focused on the mental and physical wellbeing of students as well as teachers.

\section{REFERENCES}

[1] S. Pokhrel, \& R. Chhetri, A Literature Review on Impact of COVID19 Pandemic on Teaching and Learning. Higher Education for the Future, 8(1), p133-141, 2021. DOI: 10.1177/2347631120983481.

[2] Worldometer. March 26, 2021. Retrieved from www.worldometers: https://www.worldometers.info/coronavirus/

[3] J. S. T. Pittman, An action research case study: digital equity and educational inclusion during an emergent COVID-19 divide, Journal for Multicultural Education, vol. ahead-of-print, no. ahead-of-print, 2021. Retrieved from: https://doi.org/10.1108/JME-09-2020-0099.

[4] C. Azorin, Beyond COVID-19 supernova. Is another education coming? Journal of Professional Capital and Community, vol. 5, no. 3/4, pp. 381-390, 2020. DOI 10.1108/JPCC-05-2020-0019.

[5] M. Suryaman, Y. Cahyono, D. Muliansyah, O. Bustani, \& P. Suryani, COVID-19 PANDEMIC AND HOME ONLINE LEARNING SYSTEM: DOES IT AFFECT THE QUALITY OF PHARMACY SCHOOL LEARNING? Sys Rev Pharm, 11(8), p524-530, 2020

[6] L. Mishra, T. Gupta, \& A. Shree, Online teaching-learning in higher education during lockdown period of COVID-19 pandemic. International Journal of Educational Research Open, 2020. https://doi.org/10.1016/j.ijedro.2020.100012.

[7] Y. Chandra, Online education during COVID-19: perception of academic stress and emotional intelligence coping strategies among college students. Asian Education and Development Studies, Vol. 10 No. 2, pp. 229-238, 2020. DOI 10.1108/AEDS-05-2020-0097.

[8] E. R. Chua, B. G. Sibbaluca, R. Miranda, G. B. Palmario, R. P. Moreno, \& J. P. Solon, THE STATUS OF THE IMPLEMENTATION OF THE E-LEARNING CLASSROOM IN SELECTED HIGHER EDUCATION INSTITUTIONS IN REGION IV-A AMIDST THE COVID-19 CRISIS. Journal of Critical Reviews, Vol 7, Issue 11, p253-258, 2020

[9] J. Seaman, The paradox of faculty voices: Views and experiences with online learning, APLU-Sloan National Commission on Online
Learning. Online learning as a strategic asset, Vol. 2, 2009. Retrieved from https://files.eric.ed.gov/fulltext/ED517311.pdf.

[10] J. Openo, Education's response to the Covid-19 Pandemic Reveals Online Education's three Enduring Challenges. Canadian Journal of Learning and Technology, Volume 46(2), 2020.

[11] UNESCO, COVID response website, March 27, 2020. Retrieved from https://en.unesco.org/: https://en.unesco.org/covid19/educationresponse

[12] A. Harris, COVID-19 - school leadership in crisis? Journal of Professional Capital and Community, pp. 321-326, 2020. DOI 10.1108/JPCC-06-2020-0045.

[13] A. K. Emon, A. R. Alif, \& M. S. Islam, Impact of COVID-19 on the Institutional Education. Asian Journal of Education and Social Studies, 11(2): 34-46, 2020. DOI: 10.9734/AJESS/2020/v11i230288.

[14] J. König, D. J. Jäger-Biela, \& N. Glutsch, Adapting to online teaching during COVID-19 school closure: teacher education and teacher competence effects among early career teachers in Germany. European Journal of Teacher Education, 43:4, 608-622, 2020. DOI 10.1080/02619768.2020.1809650.

[15] S. G. Huber, \& C. Helm, COVID-19 and schooling: evaluation, assessment and accountability in times of crises - reacting quickly to explore key issues for policy, practice and research with the school barometer. Educational Assessment, Evaluation and Accountability, 32:237-270, 2020. https://doi.org/10.1007/s11092-020-09322-y.

[16] C. Tan, The impact of COVID-19 on student motivation, community of inquiry and learning performance. Asian Education and Development Studies, Vol. 10 No. 2, pp. 308-321, 2021. DOI 10.1108/AEDS-05-2020-0084.

[17] L. M. Lorente, A. A. Arrabal, \& C. Pulido-Montes, The Right to Education and ICT during COVID-19: An International Perspective. sustainability, 12, 9091, 2020. doi:10.3390/su12219091.

[18] M. Adnan, \& K. Anwar, Online learning amid the COVID-19 pandemic: Students' perspectives. Journal of Pedagogical Sociology and Psychology, Volume 2, Issue 1 , 2020 http://www.doi.org/10.33902/JPSP. 2020261309.

[19] J. Z. Tria, International Journal of Pedagogical Development and Lifelong Learning. The COVID-19 Pandemic through the Lens of Education in the Philippines: The New Normal, 1(1), ep2001, 2020.

[20] S. Shehzadi, Q. A. Nisar, M. S. Hussain, M. F. Basheer, W. U. Hameed, \& N. I. Chaudhry, The role of digital learning toward students' satisfaction and university brand image at educational institutes of Pakistan: a post-effect of COVID-19. Asian Education and Development Studies, Vol. 10 No. 2, pp. 276-294, 2021. DOI 10.1108/AEDS-04-2020-0063.

[21] R. Bordoloi, P. Das, \& K. Das, Perception towards online/blended learning at the time of Covid-19 pandemic: an academic analytics in the Indian context. Asian Association of Open Universities Journal, Emerald Publishing Limited, vol. ahead-of-print, no. ahead-of-print, 2021. DOI 10.1108/AAOUJ-09-2020-0079.

[22] C. J. Thomas, Coronavirus and challenging times for education in developing countries, April 13, 2020. Retrieved from www.brookings.edu: https://www.brookings.edu/blog/education-plusdevelopment/2020/04/13/coronavirus-and-challenging-times-foreducation-in-developing-countries/.

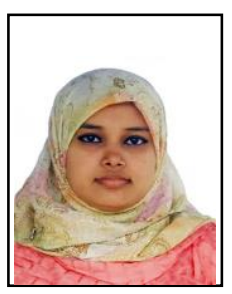

Mansura Nusrat was born in 1990 in Dhaka, Bangladesh. She lived in Chittaggong, Bangladesh from the age of Five until she moved to Dhaka, Bangladesh after her post-graduation. She has received her MBA degree (International Management) and BBA degree (Management) from University of Chittagong, Bangladesh in the year 2014 and 2013 respectively.

Her research interest encompasses areas like: Soft skill development, Employee welfare, Organization citizenship Behavior etc.

She started her career as a full-time lecturer in Management at the Department of Business Administration, Bangladesh University in the year 2015. Since, 2018 she is working as a senior Lecturer over there. 